\title{
Evidence of Stable Foraminifera Biomineralization during the Last Two Climate Cycles in the Tropical Atlantic Ocean
}

\author{
Stergios D. Zarkogiannis ${ }^{1, *} \oplus$, Assimina Antonarakou ${ }^{1}$, Vincent Fernandez ${ }^{2} \oplus$, \\ P. Graham Mortyn ${ }^{3,4}{ }^{\mathbb{D}}$, George Kontakiotis ${ }^{1} \mathbb{D}$, Hara Drinia ${ }^{1}$ and Mervyn Greaves ${ }^{5}(\mathbb{C}$ \\ 1 Department of Historical Geology-Paleontology, Faculty of Geology \& Geoenvironment, \\ School of Earth Sciences, National \& Kapodistrian University of Athens, Zografou University Hill, \\ 15784 Athens, Greece; aantonar@geol.uoa.gr (A.A.); gkontak@geol.uoa.gr (G.K.); cntrinia@geol.uoa.gr (H.D.) \\ 2 Imaging and Analysis Centre, Natural History Museum, London SW7 5BD, UK; v.fernandez@nhm.ac.uk \\ 3 Institute of Environmental Science and Technology (ICTA), Universitat Autònoma de Barcelona, \\ 08193 Barcelona, Spain; graham.mortyn@uab.cat \\ 4 Department of Geography, Universitat Autònoma de Barcelona, 08193 Barcelona, Spain \\ 5 Department of Earth Sciences, University of Cambridge, Cambridge CB2 3EQ, UK; mg109@cam.ac.uk \\ * Correspondence: stergiosz@geol.uoa.gr
}

Received: 13 August 2020; Accepted: 21 September 2020; Published: 24 September 2020

\begin{abstract}
Planktonic foraminiferal biomineralization intensity, reflected by the weight of their shell calcite mass, affects global carbonate deposition and is known to follow climatic cycles by being increased during glacial stages and decreased during interglacial stages. Here, we measure the dissolution state and the mass of the shells of the planktonic foraminifera species Globigerina bulloides from a Tropical Eastern North Atlantic site over the last two glacial-interglacial climatic transitions, and we report no major changes in plankton calcite production with the atmospheric $p \mathrm{CO}_{2}$ variations. We attribute this consistency in foraminifera calcification to the climatic and hydrological stability of the tropical regions. However, we recorded increased shell masses midway through the penultimate deglaciation (Termination II). In order to elucidate the cause of the increased shell weights, we performed $\delta^{18} \mathrm{O}, \mathrm{Mg} / \mathrm{Ca}$, and $\mu \mathrm{CT}$ measurements on the same shells from a number of samples surrounding this event. Compared with the lighter ones, we find that the foraminifera of increased weight are internally contaminated by sediment infilling and that their shell masses respond to local surface seawater density changes.
\end{abstract}

Keywords: planktonic foraminifera; shell weight; climate variability; sea surface density; carbonate production; X-ray microscopy $(\mu \mathrm{CT}) ; \delta^{18} \mathrm{O}$ and $\mathrm{Mg} / \mathrm{Ca}$ analyses

\section{Introduction}

Planktonic foraminifera are important marine calcifiers, and the ongoing change in the oceanic carbon system makes it essential to understand the influence of environmental factors on the biomineralization of their shells [1]. Although shell weight is a prominent, easily measured feature of foraminiferal tests that has direct implications for the carbon cycle and carbonate budgets, it is currently not being widely recorded or discussed because its exact environmental meaning is unclear. The amount of calcite deposited by planktonic foraminifera during calcification has been hypothesized to reflect a range of environmental factors. Through the years, changes in planktonic foraminifera shell weights have been linked to different biotic and abiotic parameters such as dissolution [2], carbonate ion concentration [3], optimum growth conditions [4], phosphate concentrations [5], temperature [6], or salinity [1], and thus the various studies have used foraminifera shell weights each time as a different 
proxy. Recent studies have shown that planktonic foraminifera can alter their shell mass according to ambient seawater density [7] and that the degree of this alteration in time is a function of latitude [8].

Planktonic organisms are able to biosynthesize out of equilibrium with their ambient environment by maintaining chemical gradients. However, as passive floaters, they must always retain equilibrium with the seawater in order to remain afloat at certain depths. It can thus be argued that plankton physiology is more sensitive to the physical rather than chemical characteristics of seawater. Because planktonic organisms lack active floatation devices, their only inert way to counterbalance seawater buoyancy changes and remain at certain depths is to modify their shell mass [9]. Shell biomineralization must thus be a function of both chemical and physical seawater properties. Although the effects of ocean chemistry on plankton have been extensively studied, there is currently a lack of literature on the effects of physical oceanic properties such as buoyancy, density, or pressure, which very likely affect foraminifera physiology and morphology [10]. Here, we examine the shell mass of the planktonic foraminifera species Globigerina bulloides (NCBI:txid69025) from a sediment core of the northeastern tropical Atlantic Ocean through the two most recent climatic cycles. After assessing the preservation of the foraminifera tests, we report consistent shell weights, and thus steady foraminiferal calcification, independent of atmospheric $p \mathrm{CO}_{2}$, in agreement with a Pliocene Caribbean record [11]. We thus attribute this consistency to the stability of the hydrological conditions over time at the tropics, because the tropical environment is strongly associated with the notion of physical and chemical stability $[12,13]$.

The stability in the foraminifera shell weights is briefly interrupted midway through Termination II, where elevated weights are recorded. In order to understand this feature, we used standard geochemical analyses $\left(\delta^{18} \mathrm{O}, \mathrm{Mg} / \mathrm{Ca}\right)$ for a set of samples that we combined with high resolution X-ray computed tomography (CT) to evaluate potential changes in the thickness of foraminifera shells [14] along with other biometric characteristics. The geochemical analyses confirmed a relationship between shell mass and water density, which is further supported by the $\mu \mathrm{CT}$ data that indicate clay contamination as the cause of the elevated shell weights. The $\mu \mathrm{CT}$ analysis also allowed the determination of cell volumes, volume normalized weights (i.e., shell density), or porosities, and has proven a valuable tool in the study of foraminifera shells. The present record provides new evidence on the response of planktonic calcifiers to ocean acidification that will help to better constrain the role that shell mass variations have on the sedimentary calcite budget and the carbon cycle.

\section{Location and Oceanographic Setting}

GeoB $8502\left(19^{\circ} 13.27^{\prime} \mathrm{N}, 18^{\circ} 56.04^{\prime} \mathrm{W}\right)$ is a Tropical North Atlantic pelagic site at the lower reaches of the Cap Timiris Canyon, approximately $250 \mathrm{~km}$ offshore the Mauritanian coast (Figure 1). The canyon head abuts the Tamanrasset River System, which, although not discharging under present-day climate conditions, ranks among the largest river systems worldwide. The mouth of this potential river system is located off Cap Timiris, but its flow pathways are at present covered by extensive Saharan sand dunes [15]. Presently, the Senegal River is the northernmost active drainage system of West Africa. Core GeoB 8502-2 was retrieved from $2956 \mathrm{~m}$ water depth on the lower Northwestern (NW) African continental rise and consists of levee sediments that are predominantly hemipelagic deposits.

Modern climate over the NW African margin is governed by the dynamics of the West African Monsoon, which is associated with the seasonal latitudinal shifts of the intertropical convergence zone (ITCZ) [16]. In winter, the equatorward displacement of the ITCZ $\left(5^{\circ} \mathrm{N}\right)$ causes a southward shift of dry subtropical air masses and is associated with the development of strong easterly Saharan Air Layer winds. The southward shift of the ITCZ and wind development cause dust transport from the Sahara [17]. The dust plume is generally located between 15 and $25^{\circ} \mathrm{N}$ along an E-W axis over the tropical Atlantic Ocean [18]. During boreal summer, dry subtropical air is shifted northward as the ITCZ is located around $20^{\circ} \mathrm{N}$ (Figure 1). This represents the onset of the rainy season (summer monsoon), with heavy rainfall and changes in atmospheric circulation [19]. Trade winds 
from the southern hemisphere, loaded with water vapor, penetrate north to the West African continent. The moisture-laden air spreads over the ocean and continent, permitting heavy rains over the area.

As part of the Eastern Boundary Current system, the Mauritanian upwelling region is one of the major upwelling areas in the Atlantic Ocean [20]. Along the NW African margin, the temporal dynamics of the coastal upwelling is driven basically by the intensity of the northeast trade-winds, itself dependent on the seasonal intertropical convergence zone (ITCZ) migration [21,22] on a perennial basis, producing cold nutrient-rich surface waters with modern sea surface temperatures (SSTs) as low as $16{ }^{\circ} \mathrm{C}$. The studied area is under the influence of the major return branch of the subtropical gyre, the Canary Current (CC), flowing southward along the north-west African coast, then becoming the North Equatorial Current (NEC) when turning southwestward and leaving the African continent. Further south, the westward flowing North Equatorial Counter Current (NECC) is encountered, which transports low salinity water in the area and is known to show a strong seasonal cycle position with maximum velocities when the ITCZ is located at the northernmost position and weak velocities in northern spring [22].

The main water masses encountered in the upwelling region are the Tropical Surface Water (TSW), the North and South Atlantic Central Waters (NACW and SACW), and the Antarctic Intermediate Water (AAIW) [22]. Because of the Cape Verde frontal zone (CVFZ), which is the transition boundary zone between NACW and SACW, the upwelling is fed by two different subsurface water masses depending on latitude [23]. The CVFZ is located at about $20^{\circ} \mathrm{N}$ off Africa oriented southwestward to about $16^{\circ} \mathrm{N}$ in the central tropical Atlantic. The front is associated with a convergence at the coast between the CC conveying NACW southward and a northward flow of SACW. With SACW and NACW occupying the same density range, the front is density-compensated and results in a multitude of intrusions, filaments, and lenses [24]. The NACW is warmer and more saline compared with the SACW. Both central water masses appear in the permanent pycnocline between depths of $150 \mathrm{~m}$ and $600 \mathrm{~m}$ at temperatures greater than about $8^{\circ} \mathrm{C}$, below which lies the AAIW [22]. At greater depths, the core sediments are currently bathed in the carbonate saturated North Atlantic Deep Water (NADW) and may have remained so during the glacials [25].

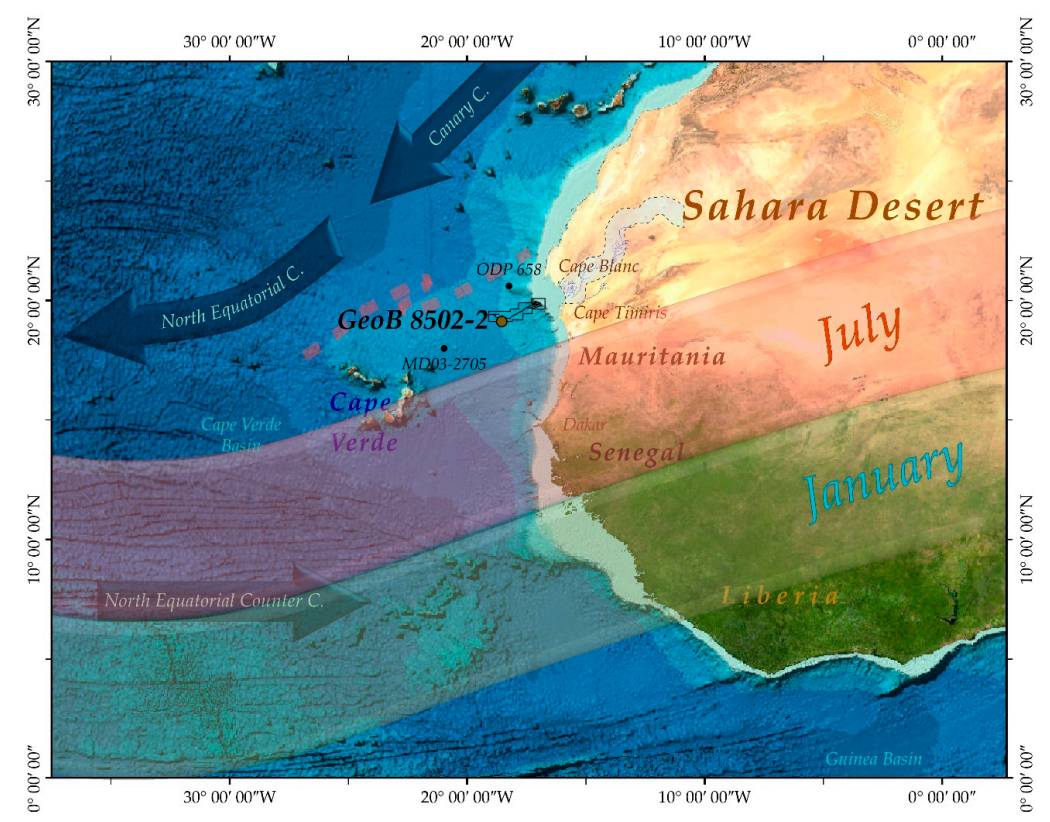

Figure 1. Location of the studied core GeoB 8502-2 along the north-western African margin compared with the atmospheric and oceanographic regional settings. The Cap Timiris Canyon pathway is marked. The arrows show the pathway of the modern dominant surface currents in the area. Red and blue bands identify the migration domains of the summer and winter intertropical convergence zone (ITCZ), respectively. The dashed red band close to the core position denotes the Cape Verde frontal zone (CVFZ) location. The Tamanrasett River paleodrainage valley is indicated, as suggested by [15]. 


\section{Materials and Methods}

GeoB $8502-2$ is $14.78 \mathrm{~m}$ long with an average sedimentation rate of $\approx 6 \mathrm{~cm} / \mathrm{ky}$ and extends back $200 \mathrm{ky}$ to Marine Isotope Stage (MIS) 6. Samples were taken at a resolution of $\sim 1700$ years (10 cm sampling interval) by extracting a slice of material, $1 \mathrm{~cm}$ in thickness, which corresponds approximately to an average of 170 years of sedimentation. All samples were freeze-dried, weighed, and washed through a $63 \mu \mathrm{m}$ sieve. They were subsequently dry-sieved into several sieve fractions and non-fragmented G. bulloides shells from the 315-355 $\mu \mathrm{m}$ size fraction were picked for mass analysis. The very narrow size interval $(40 \mu \mathrm{m})$ should be sufficient to overcome the greater proportion of natural size variability without further normalization [26]. Furthermore, this size fraction is widely used in paleoceanographic studies and can allow comparisons. However, any record of shell weight is a composite signal of dissolution superimposed upon initial shell weight variability.

In order to assess whether the influence of dissolution is responsible for the observed shell weights, the preservation state of the specimens underwent multiproxy assessment. Moreover, to better understand the increase in G. bulloides shell mass during Termination II (T-II), the selected specimens were analyzed both geochemically and by high resolution X-ray microcomputed tomography $(\mu \mathrm{CT})$. $\mu \mathrm{CT}$ was used to inspect the interior and the internal structure of the foraminiferal tests, and apart from addressing the test's integrity (manifestation of dissolution), we were also able to assess to what degree the increased recorded masses are the result of interference from shell inclusions or of changes in test thickness. Finally, the XMCT analysis led to total shell volume estimates that allowed the calculation for the first time of volume normalized shell weights or G. bulloides shell densities, presenting a more precise method of eliminating the contribution of shell size to shell weight.

\subsection{Weight Analysis}

Where available, ideally, 50 (minimum 38) G. bulloides shells were weighed in a preweighed aluminum carrier using a Sartorius CP2P microbalance with a precision of $\pm 1 \mu \mathrm{g}$. Average shell masses were calculated by dividing the recorded mass by the total number of foraminifera weighed. Subsequently, for each sample, each shell was weighed separately, in order to estimate standard shell mass deviations. As explained above, performing shell weight analyses on a narrow size fraction of foraminifera constrains the ontogenic stage of the specimens to a certain number of chambers, and thus minimizes size-related weight differences [26-28]). The analytical error, estimated by triplicate measurements of 50 random specimens, ranged from 0.42 to $0.58 \mu \mathrm{g}$, which is in accordance with the error of the balance.

\subsection{Dissolution Assesment}

Because of the immediate impact of dissolution on shell mass, a multiproxy approach was applied to determine the preservation state of the foraminiferal carbonate because indirect dissolution proxies may respond to influences other than dissolution alone. First, the conventional fragmentation index (F.I.) was counted in a sub-split of ( 300) particles from the 315-355 $\mu \mathrm{m}$ sieve fraction. Subsequently, 30 of the weighed specimens was mounted for ultrastructural examination under the SEM using the G. bulloides dissolution index (BDX'). As this species has a high dissolution susceptibility ranking [29], it is a reliable indicator of the foraminiferal carbonate preservation state. The BDX' [30] is based on the direct assessment of corrosion of the specimen's surface and consists of distinct dissolution stages that are determined by the decreasing preservation state of the four ultrastructural test features: pores, interpore space, spines, and ridges. As dissolution proceeds, pores are widened, the interpore areas are etched, and ridges and spines become denuded until the specimen is finally broken down. It thus consists of six stages worsening from 0 to 5 , with severe dissolution starting above stage 3 . The SEM analysis was performed with a Zeiss DSM 940A SEM in the Department of Geosciences at the University of Bremen. 


\subsection{X-ray Micro-Computed Tomography $(\mu \mathrm{CT})$}

For X-ray microscopic analysis, in total, 27 specimens were scanned from 3 samples $(9$ specimens per sample) that correspond to the time interval of the increased mass event (132.2 ka), the penultimate glacial maximum $(139.1 \mathrm{ka})$ prior to the event, and a time interval of increased shell weights that followed $(122.5 \mathrm{ka})$. Each batch of shells was poured into a quartz cylindrical carrier $1 \mathrm{~mm}$ in diameter [31]. They were stabilized with diluted tragacanth glue and left to dry prior to scanning. The specimens were subsequently retrieved for the geochemical analyses. The micro-CT $(\mu \mathrm{CT})$ scanning was carried out with a Zeiss Versa 520 at the X-ray Microscopy laboratory of London Natural History Museum. X-ray source and detector geometry were kept constant throughout the scans. Anode voltage was set at $100 \mathrm{kV}$, the X-ray tube current was $90 \mu \mathrm{A}$, and the exposure time was $2 \mathrm{~s}$ at an optical magnification of $4 \times$. By processing approximately 1024 images per sample, a scan resolution voxel size of $\sim 1.2 \mu \mathrm{m}^{3}$ was typically achieved using this set up in order to maximize the number of specimens that could be analysed in a single scan. The images were combined to build a 3D rendering using Avizo software, which was also used for segmentation. The segmentation resulted in the separation of the tomographs into shell area, area occupied by clay infillings (dirt), and internal shell (protoplasm) voids (Figure 2).

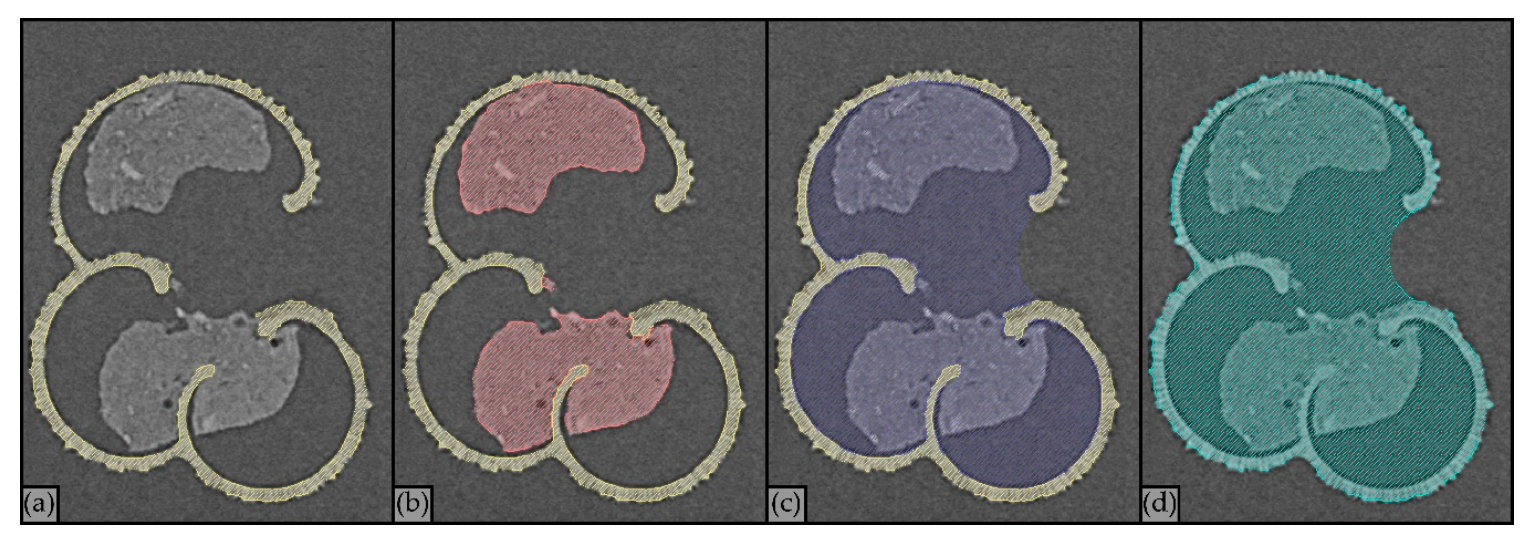

Figure 2. Example of tomograph segmentation using computed tomography (CT) data visualization software, where (a) in yellow, the foraminifera test is solely segmented; (b) in red, the area covered by dirt was also segmented; (c) dirt and internal (chamber) voids were considered together to calculate the area that was occupied by protoplasm (in blue); and (d) protoplasm and shell areas were merged together (in cyan) to calculate the total volume occupied by a foraminifer.

Subject to the degree of segmentation, the $\mathrm{X}$-ray microscopic analysis allows the determination and study of a number of biometric characteristics of the foraminifera shells, such as total shell volume (Figure 2d), thus shell density (volume normalized weight) and calcite (test) volume, and thus test density [32] and calcite (test) surface (Figure 2a). The ratio of calcite volume/calcite surface provides a linear unidimensional quantity in length units and can thus serve as a measure of average test thickness. In this study, in addition to shell density, that is, the ratio of shell volume to shell mass, we use the "specific surface area", that is, the ratio of test volume/test surface, as a measure of average test thickness [32] and the test density, that is, the ratio of test volume to shell mass, as an indication of test porosity. Furthermore, by segmenting the area occupied by clay infillings, we were able to calculate by volume percent the degree of contamination in weight measurements.

\subsection{Geochemical Analysis}

In order to reconstruct the oceanographic regime of the time interval surrounding the increased shell mass event during T-II, 12 adjacent down core samples, covering the period of $\sim 22,000$ years between 119 and $140 \mathrm{ka}$, were geochemically analysed to determine shell $\mathrm{Mg} / \mathrm{Ca}$ ratios for seawater temperature estimations and $\delta^{18} \mathrm{O}$ isotope $\left(\delta^{18} \mathrm{O}_{\text {shell }}\right) . \mathrm{Mg}$-derived temperatures and foraminiferal 
$\delta^{18} \mathrm{O}_{\text {shell }}$ were used together to assess changes in seawater $\delta^{18} \mathrm{O}\left(\delta^{18} \mathrm{O}_{\mathrm{sw}}\right)$ composition. $\mathrm{Mg} / \mathrm{Ca}$ ratios were converted to temperatures using an equation for temperate ranges [33]. $\delta^{18} \mathrm{O}_{\mathrm{sw}}$ was calculated using a published paleotemperature equation [34], and a VPDB-to-SMOW $\delta^{18} \mathrm{O}$ conversion of $0.27 \%$ o [35]. Salinity estimates were derived from $\delta^{18} \mathrm{O}_{\mathrm{sw}}$ using the tropical Atlantic salinity- $\delta^{18} \mathrm{O}_{\mathrm{sw}}$ relationship [36] and corrected for deglacial whole ocean salinity changes using a $120 \mathrm{~m}$ scaled sea-level curve [37] and an average ocean depth of $3800 \mathrm{~m}$. Seawater densities were calculated from temperature and salinity estimates using the equation state of the water [38] at a (G. bulloides calcification) depth of $100 \mathrm{~m}$. In order to test the correlation between shell mass and the different environmental and oceanographic data, two-tailed regression analyses were performed using the reduced major axis model, at $n-1$ degrees of freedom ( $n$ representing sample size).

\subsubsection{Oxygen Stable Isotope Determination}

For oxygen isotopes determination, on average, five G. bulloides tests from each sample were transferred into sample vials, crushed, and then dried in an oven at $50{ }^{\circ} \mathrm{C}$. The vials were loaded into the carousel and analysed using a Thermo Kiel device attached to a Thermo MAT253 Mass Spectrometer in dual inlet mode at The Godwin Laboratory for Paleoclimate Research, Department of Earth Sciences, University of Cambridge. The preparation system operates automatically, analysing samples in sequence. Then, $100 \%$ orthophosphoric acid is dropped onto the evacuated vial and reacts with the calcium carbonate sample. The evolved carbon dioxide is cryogenically dried and then admitted to the dual inlet mass spectrometer for isotopic analysis by comparison with a reference gas. Each run of 30 samples was accompanied by 10 reference carbonates and 2 control samples. The results are reported with reference to the international standard VPDB and the precision is better than \pm 0.06 per mil for $\delta^{13} \mathrm{C}$ and \pm 0.08 per mil for $\delta^{18} \mathrm{O}$.

\subsection{2. $\mathrm{Mg} / \mathrm{Ca}$ Determination}

On average, $15 \mathrm{G}$. bulloides tests from each sample were used for $\mathrm{Mg} / \mathrm{Ca}$ determination. The specimens were cleaned using the standard protocol [39], omitting the reductive treatment, and were analysed for $\mathrm{Mg} / \mathrm{Ca}$ ratios by inductively coupled plasma optical emission spectrometry (ICP-OES) using an Agilent 5100 instrument at the Godwin Laboratory for Paleoclimate Research, Department of Earth Sciences, University of Cambridge. Samples were dissolved in $0.1 \mathrm{M} \mathrm{HNO}_{3}$ and centrifuged to remove any undissolved material. After an initial run to determine Ca concentration, samples were diluted to constant [Ca] (100 ppm). $\mathrm{Mg} / \mathrm{Ca}$ ratios were determined by the intensity ratio method of [40] using calibration standards prepared according to [41]. Cleaning efficiency and diagenetic effects were monitored by measuring $\mathrm{Fe} / \mathrm{Ca}, \mathrm{Mn} / \mathrm{Ca}, \mathrm{Al} / \mathrm{Ca}, \mathrm{Si} / \mathrm{Ca}$, and $\mathrm{Ba} / \mathrm{Ca}$ ratios.

The instrumental precision for the $\mathrm{Mg} / \mathrm{Ca}$ ratios is $\pm 0.51 \%$, determined by replicate analyses of a standard solution containing $\mathrm{Mg} / \mathrm{Ca}$ ratios of $1.3 \mathrm{mmol} \mathrm{mol}^{-1}$ and a Ca concentration of $100 \mathrm{ppm}$. The accuracy of $\mathrm{Mg} / \mathrm{Ca}$ ratios has been established by interlaboratory calibration [42] Sample heterogeneity for $\mathrm{Mg} / \mathrm{Ca}$ ratios has been shown to be much greater than instrumental precision $[39,43]$. We estimate the reproducibility of planktonic foraminiferal $\mathrm{Mg} / \mathrm{Ca}$ ratios as $\sim 8 \%$ from replicate analyses of G. bulloides picked from an Atlantic core-top sample.

\section{Results}

The record of G. bulloides shell mass attained from GeoB 8502-2 for the last 200 ky shows no distinct mode of variability (Figure 3a). In general, shell weights are stable, fluctuating only on a small scale $( \pm 1.1 \mu \mathrm{g}, 1 \sigma)$ around an average of $13.4 \mu \mathrm{g}$. They thus do not exhibit any glacial-interglacial cyclicity or follow the atmospheric $p \mathrm{CO}_{2}$ fluctuations (Figure 3d). Lower shell mass weights are found within MIS 6, while values almost increase progressively after MIS 5.2. Superimposed on this pattern is a broad maximum in shell weight centred on the MIS 5/6 boundary of T-II with a duration of approximately $2300 \mathrm{yr}$, during which shell masses increase by $30 \%$ above average. 


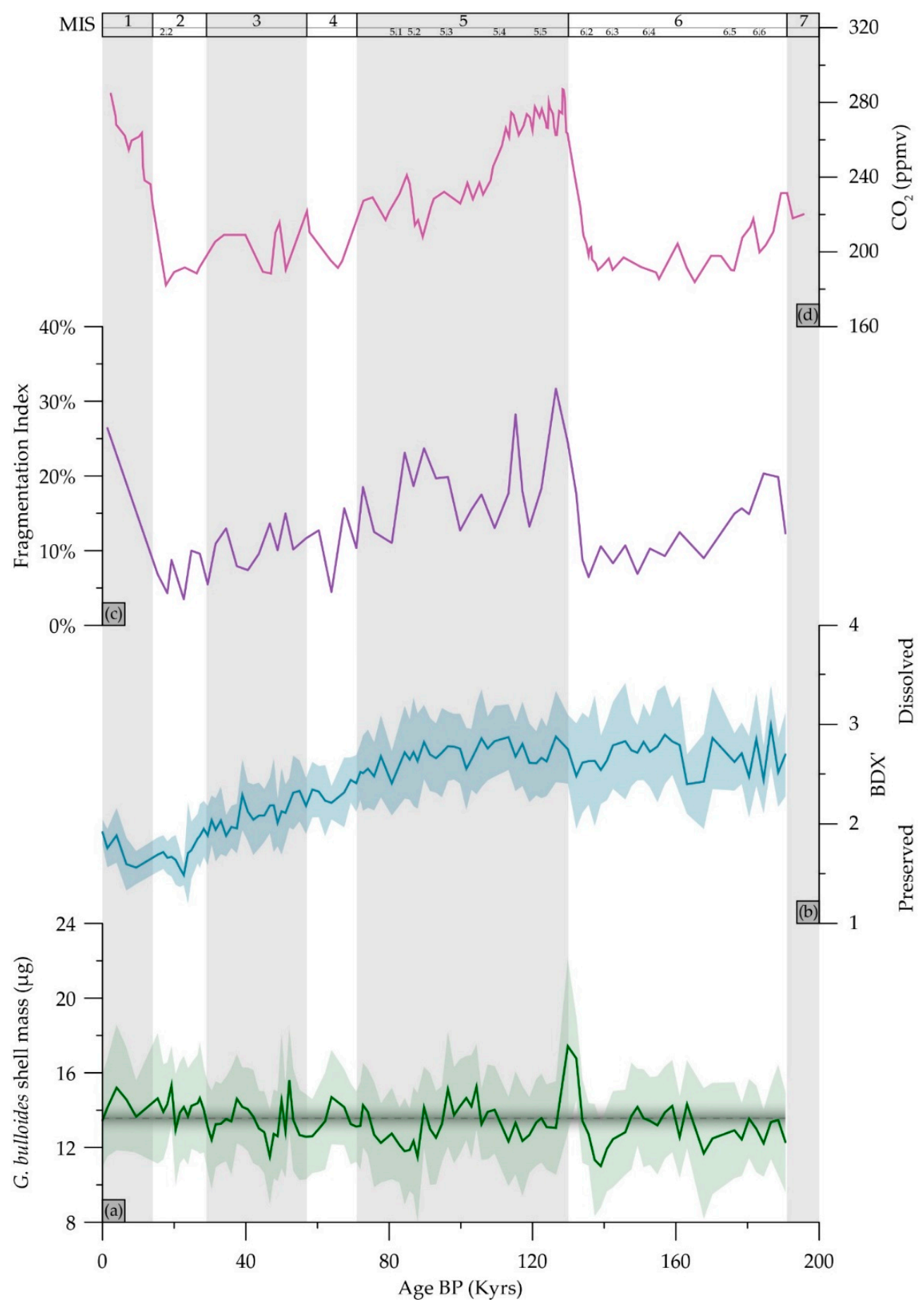

Figure 3. Climatic records of the last $200 \mathrm{ky}$ (before present; BP): (a) G. bulloides average shell mass record from GeoB 8502-2. The grey line denotes the record's mean shell mass and the $1 \sigma$ confidence interval is indicated by the shading; (b) specimen's preservation assessment using the Bulloides dissolution index $\left(\mathrm{BDX}^{\prime}\right)$; (c) the fragmentation index of the coarse fraction; and (d) the record of atmospheric $\mathrm{CO}_{2}$ from Vostok [44] is shown for comparison. The $1 \sigma$ confidence interval for the shell mass and BDX' plots shown as transparent polygons. Numbers refer to Marine Isotopic Stages (MIS) or substages and grey shaded areas interglacial periods. Data are available in Supplementary Tables.

The multiproxy carbonate preservation assessment of the studied core is shown in Figures 2c and 3b. The record of fragmentation strikingly parallels that of the atmospheric $p \mathrm{CO}_{2}$, indicating the influence of carbonate chemistry changes on the study samples. Nonetheless, this influence does not prove 
sufficient to severely alter foraminifera shell mass. In general, foraminiferal carbonate is found to be well preserved (Figures 2c and 3b), because any severe dissolution takes place after BDX' values of 3 [30]. The BDX' and the F.I. assessments (Figures $2 \mathrm{c}$ and $3 \mathrm{~b}$ respectively) are in agreement, indicating that the preservation becomes better during the course of the last glacial period. However, regardless of the increase in foraminifera fragmentation after the Last Glacial Maximum, the G. bulloides specimens' ultrastructure was not found to be corroded. A similar disagreement between the dissolution proxies exists for MIS 6, where, although the surface ultrastructure of G. bulloides specimens shows signs of corrosion, overall foraminiferal breakage is found to be limited. The deteriorated shell preservation state during MIS 6, as suggested by the BDX', might be adequate to explain to some extent the slightly decreased G. bulloides shell weight values of this period, but on the other hand, the gradual decrease of the BDX' values towards the present may explain a gradual increase in mass.

The results of the geochemical analyses of the samples surrounding T-II are summarized in Figure 4 together with a focused record of G. bulloides shell weights, atmospheric $p \mathrm{CO}_{2}$, and relative sea level. $\delta^{18} \mathrm{O}$ ranges from -0.09 to $0.71 \%$ ond, with the exception of the first sample in MIS 6, in general, they are found to be more depleted within the glacial period. The most depleted value is found near MIS $6.2(133.9 \mathrm{ka})$, after which values start to increase and become heavier during the Eemian. $\mathrm{Mg} / \mathrm{Ca}$ ratios range from 2.33 to $4.15 \mathrm{mmol} / \mathrm{mol}$, but are in general consistent around $2.8 \mathrm{mmol} / \mathrm{mol}$ during this period. However, they are slightly more depleted prior to the termination and exhibit a spike with a $\sim 46 \%$ increase in their values during the MIS 6.1 interstadial. This increase should indicate an environmental signal as all the contamination indicators ( $\mathrm{Fe}, \mathrm{Al}$, and so on) were low for this sample.

The results of the $\mu \mathrm{CT}$ analysis of the samples covering the $22 \mathrm{ky}$ interval surrounding the $30 \%$ increase in shell weight event during T-II are summarized in Table 1. Shells are on average $16 \%$ thicker during the time that they are heavier (132.2 ka), with a mean thickness of $5.7 \mu \mathrm{m}$. They are also $\sim 32 \%$ more voluminous/larger within the same sieve fraction during the same time, but with the highest size variability. Apart from being larger and thicker, they are also found to be more than threefold contaminated by clay infillings (19\% of their interior void), thus the observed increase in weight is a result of both enhanced biomineralization and contamination. Shell densities or volume normalized weights do not change significantly (up to $7 \%$ from the densest during the time of the highest masses to the lightest during the interglacial), but values show high variability. In terms of test density or porosity, the heaviest and densest shells are only intermediate porous.

Table 1. Average biometric data of foraminifera from weighing and $\mu \mathrm{CT}$ (computed tomography) analysis. Test thickness is the ratio of calcite volume to calcite surface, and shell and test density are the ratio of the average shell weight to test and shell volume, respectively (see Section 3.3 for details). Sediment infilling is the specimen's internal volume percentage occupied by sediment impurities. The $\mu \mathrm{CT}$ analysis results for individual specimens are published in an accompanying paper [31].

\begin{tabular}{cccccccc}
\hline Sample & $\begin{array}{c}\text { Age } \\
(\mathbf{k y r s})\end{array}$ & $\begin{array}{c}\text { Test Mass } \\
(\boldsymbol{\mu g})\end{array}$ & $\begin{array}{c}\text { Test Thickness } \\
(\boldsymbol{\mu \mathbf { m } )}\end{array}$ & $\begin{array}{c}\text { Cell Volume } \\
\left(\boldsymbol{\mu m}^{\mathbf{3}}\right)\end{array}$ & $\begin{array}{c}\text { Sediment } \\
\text { Infilling }\end{array}$ & $\begin{array}{c}\text { Shell Density } \\
\left(\mathbf{g} / \mathbf{c m}^{\mathbf{3}}\right)\end{array}$ & $\begin{array}{c}\text { Test Density } \\
\left(\mathbf{g} / \mathbf{c m}^{3}\right)\end{array}$ \\
\hline 785 & 122.5 & $13.6 \pm 2.4$ & $5.0 \pm 0.4$ & $22,326,089 \pm 11 \%$ & $5 \%$ & $0.61 \pm 0.12$ & $35 \pm 7$ \\
825 & 132.2 & $16.8 \pm 2.2$ & $5.7 \pm 0.5$ & $24,126,844 \pm 22 \%$ & $19 \%$ & $0.69 \pm 0.18$ & $21 \pm 6$ \\
865 & 139.1 & $11.0 \pm 2.2$ & $4.8 \pm 0.5$ & $19,091,400 \pm 17 \%$ & $4 \%$ & $0.58 \pm 0.15$ & $17 \pm 4$ \\
\hline
\end{tabular}

Sample 865 at 139.1 ka should record the Penultimate Glacial Maximum (PGM) in the present archive, which, in the northern hemisphere, is placed at $140 \mathrm{ka}$ BP [45], because after that, the sea level and atmospheric $\mathrm{CO}_{2}$ rise continuously (Figure 4). The low shell weights recorded during this period indicate reduced calcification, which is further supported by the $\mu \mathrm{CT}$ scans, which reveal small, thin, and highly porous shells of low density. The scanned shells closest to the peak of the Eemian interglacial period were found to be of average mass, intermediate size, thickness, and density, but were also the least porous. The interior of the Eemian and PGM specimens was found to be filled with sediment by only $5 \%$ and $4 \%$, respectively, thus with minimum distortions to the weight measurements. 


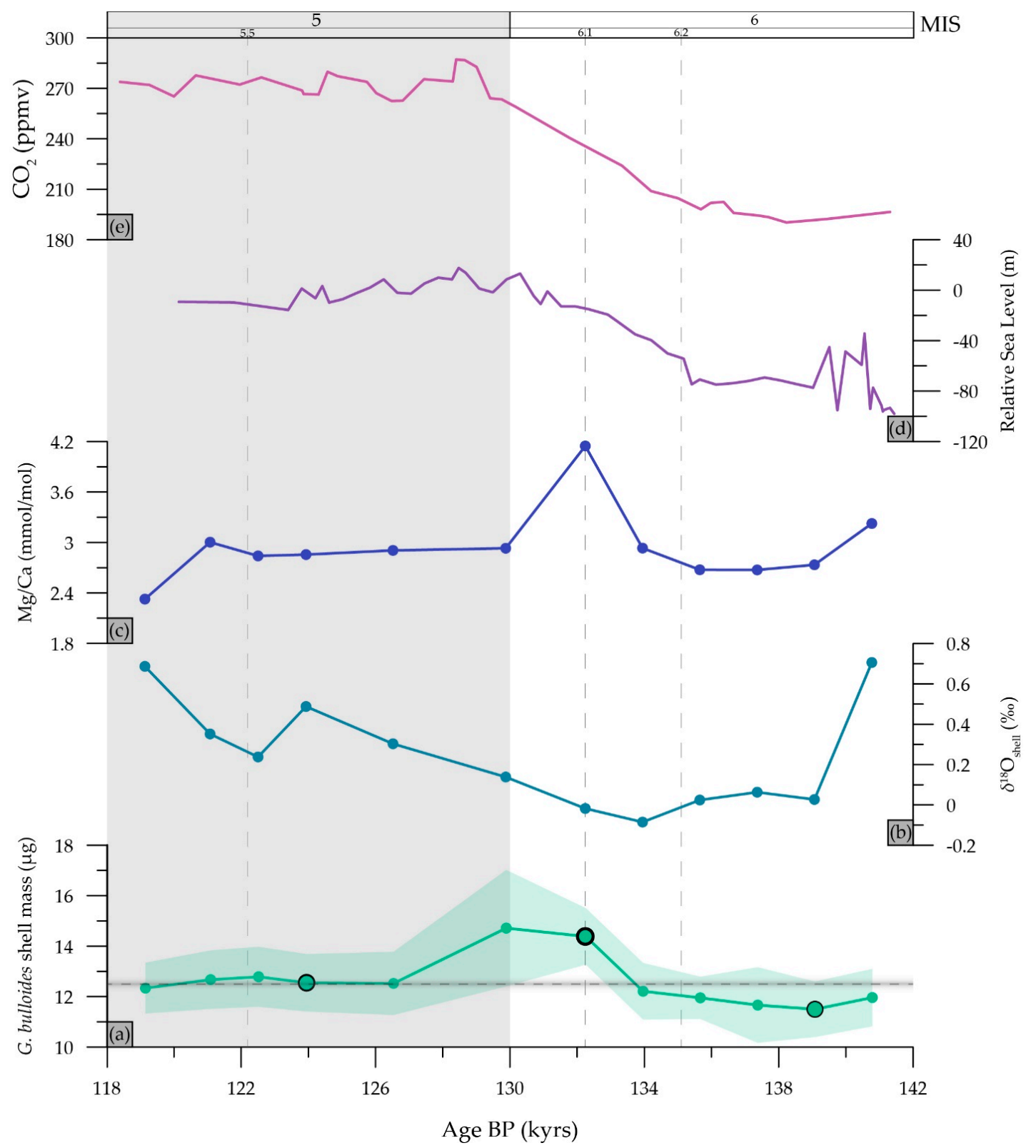

Figure 4. Climatic and geochemical records of the period surrounding the increased G. bulloides shell mass events during T-II: (a) average G. bulloides shell mass from GeoB 8502-2. The grey line denotes the mean shell mass of this period and the shading is the $1 \sigma$ confidence interval. Enlarged circles denote the samples that have been X-ray microscopically analysed. The thickness of their envelope line is proportional to the average shell wall thickness shown in Table 1 ; (b) $\delta^{18} \mathrm{O}_{\text {shell }}$ of the foraminiferal calcite; (c) $\mathrm{Mg} / \mathrm{Ca}$ ratios of the foraminiferal calcite; (d) the relative sea level record [46] is shown for comparison and (e) the record of atmospheric $\mathrm{CO}_{2}$ from Vostok [44] is also shown for comparison. The $1 \sigma$ confidence interval for the shell mass plot is shown as transparent polygons. Numbers refer to Marine Isotopic Stages and substages. Geochemical and shell mass data are available in the Supplementary Tables.

The geochemical analyses allow the reconstruction of the physical oceanographic parameters that characterize the period surrounding T-II at the study area and are shown in Figure 5a-c. Temperatures are relatively stable at around $17^{\circ} \mathrm{C}$ and they are only slightly lower, in comparison with during MIS 5.5, for most of the late MIS 6 glacial. During the MIS 6.1 interstadial peak, the temperature rises to $20.3{ }^{\circ} \mathrm{C}$, while after the Eemian peak, it drops to $14.8^{\circ} \mathrm{C}$. The salinity reconstructions show 
strong changes in the salt content during this time, with a drop in salinity from $\sim 34$ to 29 psu for 3400 years between 139.1 and $135.7 \mathrm{ka}$, and then a $24 \%$ increase to $\sim 38 \mathrm{psu}$ after the PGM before decreasing back to 34 at the peak interglacial. The same applies with the reconstructed densities of the water column that reveal lighter waters during the glacial and denser waters after MIS 6.1. Following the previous study [7], shell weights were plotted against the reconstructed seawater density values and a significant $\left(\mathrm{R}^{2}=0.43, p<0.05, n=12\right)$ relationship between these parameters was verified (Figure $5 \mathrm{~d}$ ), which becomes even more significant $\left(\mathrm{R}^{2}=0.74, p<0.01, n=12\right)$ if the (upper right) two heaviest (most contaminated by clay infillings) samples are omitted. It is evident that these two samples of excessive shell weights deviate from the resulting regression line. If this regression line dictates shell mass according to the shell's geochemical signal, then we can infer that these two samples are contaminated with $2-3 \mu \mathrm{g}$ of sediment.
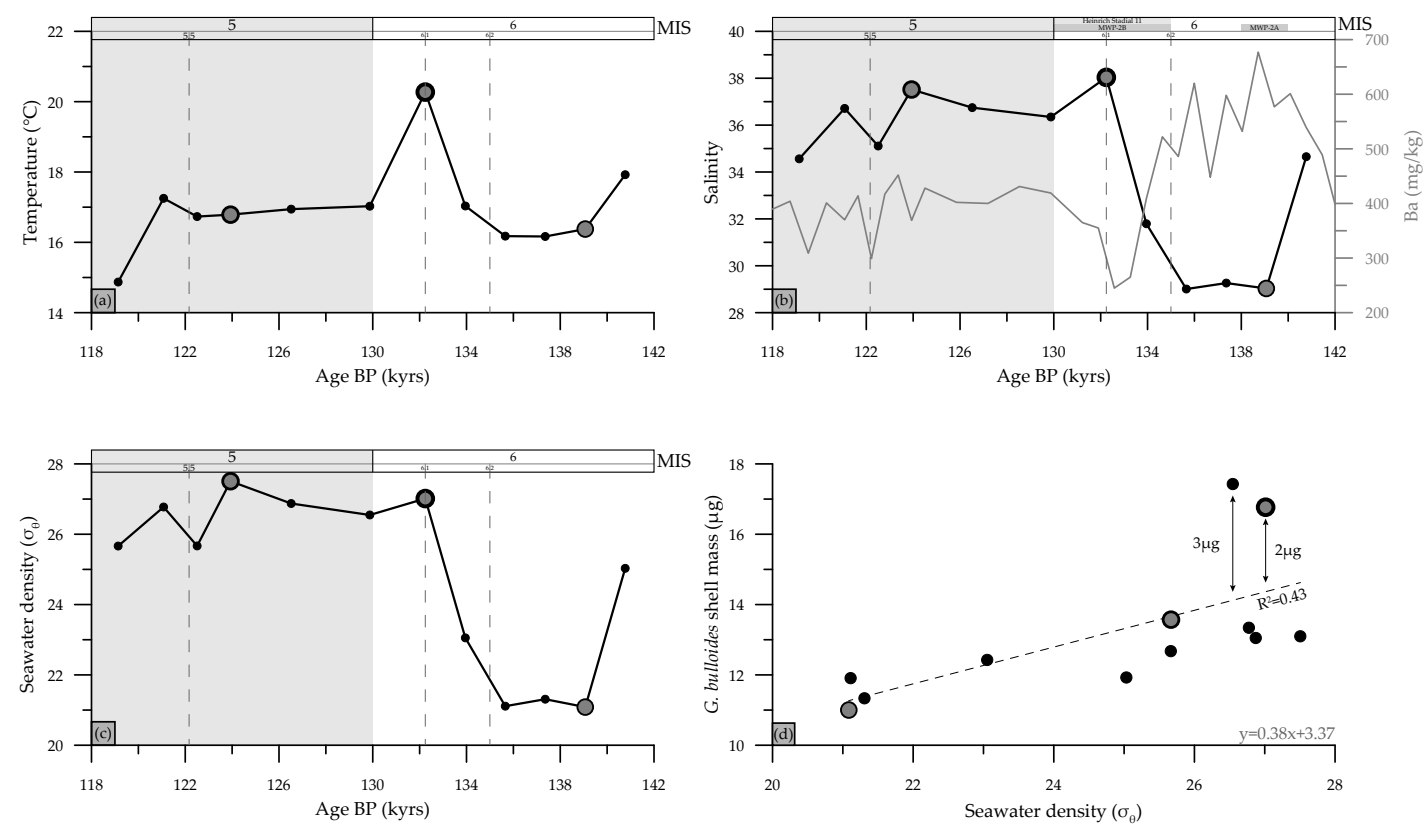

Figure 5. Geochemically reconstructed physical oceanographic parameters for the period surrounding T-II and their relation to average G. bulloides shell weights: (a) temperature estimates based on $\mathrm{Mg} / \mathrm{Ca}$ ratios; (b) salinity reconstructions based on coupled $\mathrm{Mg} / \mathrm{Ca}$ and $\delta^{18} \mathrm{O}$ measurements together with Barium (Ba) X-ray fluorescence (XRF) counts; (c) ambient seawater density reconstructions based on the preceding temperature and salinity estimates; (d) shell mass and seawater density regression plot. The two upper right points are the increased shell mass samples that deviate from the regression line by 2 and $3 \mu \mathrm{g}$, respectively. At the lower right, the contamination corrected regression equation is shown. Enlarged circles denote the samples that have been X-ray microscopically analysed. The thickness of their envelope line is proportional to the average shell wall thickness shown in Table 1. Data are available in the Supplementary Tables and XRF data from [47].

\section{Discussion}

The sieved based weight analysis of G. bulloides shells from the tropical Atlantic core GeoB8502-2 revealed a typical value of $13.4 \mu \mathrm{g}$ and only small variability in the average mass throughout the last two climatic cycles, which does not follow the atmospheric $p \mathrm{CO}_{2}$ record. This stability in planktonic foraminifera shell masses despite changes in atmospheric $p \mathrm{CO}_{2}$ has also been reported in similar latitudes for the Pliocene [48], and may be the result of the environmental stability of the tropical regions. The tropics are generally an environment in which the physicochemical factors are not undergoing major changes through time [12] and this hydrological stability can explain the observed stability in the foraminifera shell weight record that we report here. The incoming solar energy varies considerably from tropical to polar latitudes. At the equatorial region, the average insolation is the highest with 
only minor peak energy changes, while at middle and high latitudes, the regular periodicities in the Earth's orbit and tilt influence the amount and distribution of incoming energy and temporal changes are greater [49].

Test weights and the range of test weights in North Atlantic Pliocene and Pleistocene G. bulloides are similar despite the higher $p \mathrm{CO}_{2}$ during the Pliocene [11]. However, the absolute G. bulloides shell mass values for specimens $300-350 \mu \mathrm{m}$ in size reported here for a tropical Atlantic site are low compared with the North Atlantic records $[48,50]$. This is consistent with the influence of seawater densities on shell weights [7], as the lowest sea surface density values are found in the tropical waters, where salinity is lowest due to excess rainfall associated with the intertropical convergence zone, and increases toward the poles [51]. At higher latitudes, G. bulloides shell weight changes by around one-third over glacial-interglacial cycles [3,50,52], and a similar variability in test weight is seen through the Pliocene glacial-interglacial cycles at a similar location [48]. At these higher latitudes that are more sensitive to (latitudinal) changes in solar radiation through time, foraminifera shell weights follow the pronounced hydrological changes between the climatic cycles, with the most sensitive latitudes for explaining the glacial/interglacial ice-dynamics around $65^{\circ}$ [53], leaving the tropical shell mass records almost invariable. The consistency in foraminifera shell mass may reflect hydrological stability in the study area, and thus stability of the ITCZ locations during the last $200 \mathrm{ky}$.

Both dissolution proxies (F.I. and BDX') agree that the biogenic carbonate preservation is generally good to very good. There is a clear match in the trends of both proxies for deterioration in the preservation of foraminifera specimens from MIS 2 to MIS 5.5. Increased specimen dissolution is also evident in the tomographs of the mid T-II sample [54]. This deteriorating trend, however, is not sufficient to cause obvious reductions in the weights of G. bulloides shells during this time interval. The two proxies disagree within MIS 6, where the degree of ultrastructural corrosion does not parallel the degree of specimens' fragmentation. This discrepancy points either to the application limits of the proxies or is the result of different test architecture. The F.I. is an indirect measure of shell dissolution and may be the result of ecologic factors like shell initial thickness or different environmental ones (e.g., degree of bioturbation), but in this case, it closely follows the atmospheric $p \mathrm{CO}_{2}$, implying an influence of carbonate chemistry. On the other hand, the BDX' assesses specimen dissolution directly, but it is more subjective than F.I. as a proxy. However, if specimens are smaller during the late MIS 6, as suggested by the CT analysis (Sample 865; Table 1), then they would have been less prone to fragmentation [55] even at a higher degree of corrosion, and this could explain the offset in the indices.

Carbonate dissolution in the equatorial Atlantic was traditionally believed to be greater during interglacial periods, mainly because of lower carbonate contents in the glacial sequences that fluctuated in response to Quaternary climatic oscillations [56-59]. However, Broecker, et al. [60] showed, in a core from the north Atlantic, that net carbonate input actually increased in the last glacial, but a proportionately higher detrital terrigenous influx diluted the carbonate, in accordance with later studies [61-63] showing that large glacial-interglacial differences in carbonate concentration are caused mainly by increased dilution by non-carbonate material during low sea levels. On the basis of the multiproxy dissolution assessment and the consistency of foraminifera shell weight, the present analysis shows that biogenic carbonate dissolution has overall been minimal in the eastern tropical north Atlantic, with a slight increase towards the peak interglacial. Slightly increased dissolution of fossil shells is to be expected during interglacials as a result of the biomineralization of dissolution susceptible higher-Mg calcite. Together with findings from the western equatorial Atlantic [63], the present study indicates that the average carbonate productivity in the tropical Atlantic has been constant during the last two climatic cycles. Furthermore, the strong carbonate preservation in the study site suggests that the Cape Verde plateau has remained under the influence of the non-corrosive NADW during the past $200 \mathrm{ky}$, the carbonate chemistry of which closely followed the atmospheric $p \mathrm{CO}_{2}$.

The homogeneity of the G. bulloides shell mass record is interrupted by a spike in the mass values during T-II, where weights increase by $30 \%$ above average. In order to explain this abnormality, a series of geochemical and tomographic analyses were performed that point to sediment contamination as 
the cause of the increase of the measured weights. The first elevated masses are recorded at $132.2 \mathrm{ka}$ during MIS 6.1, where high $\mathrm{Mg} / \mathrm{Ca}$ temperatures are also recorded, and persisted for approximately 2400 years. With the exception of MIS 6.1, when $20.3^{\circ} \mathrm{C}$ was reconstructed, temperatures in the area are relatively stable around $16-17^{\circ} \mathrm{C}$ and only slightly reduced during glacial times. For comparison, in the upwelling region of the area, the full range of glacial to interglacial temperature changes amounted to more than $6{ }^{\circ} \mathrm{C}[64]$, and such variations in SST most probably result from changes in the intensity of coastal upwelling, and in turn the consequence of fluctuations in trade-wind strength [65]. Peak warm stages, accordingly, correspond to a cessation of upwelling and trade winds. Indeed, temperatures of $25^{\circ} \mathrm{C}$ are characteristic of the subtropical Atlantic outside the upwelling region [66]. T-II is defined by the fairly gradual $\delta^{18} \mathrm{O}_{\text {shell }}$ decrease between substages 6.2 and 5.5, as has been manifested for the study area before [67]. Coupled $\delta^{18} \mathrm{O}_{\text {shell }}-\mathrm{Mg} / \mathrm{Ca}$ derived salinities and densities reveal that, because temperatures are relatively stable during this time interval, it is salinity that dictates the sea surface density (SSD) and major hydrological changes in the area take place after MIS 6.1, when salinities return to normal marine conditions.

During the late MIS 6, the geochemical data suggest salinities as low as 29 for 3500 years. The presence of a less-saline water surface layer will most often lead to reduced production, as higher density differences will slow down the upwelling system. T-II contains two major meltwater pulses [68] (MWP-2A and MWP-2B) that, on one hand, can explain low salinities, which are centered on $139 \pm 1$ and $133 \pm 1 \mathrm{ka}$ [69], and coincided within uncertainties with two North Atlantic cooling episodes [70]. MWP-2A indicates an early phase of ice-sheet retreat. MWP-2B is more convincingly resolved and marks a steep $\sim 70 \mathrm{~m}$ sea-level rise ( $70 \%$ of the glacial-interglacial change) at rates of $28 \pm 8 \mathrm{~m}$ $\mathrm{ky}^{-1}[68,69]$. Although small scale perturbations in SSSs and SSDs such as during MIS 5.5 may have been explained by changes in the position of CVFZ and, accordingly, shifts in the influence of NACW and SACW, salinities in the order of 29 indicate the influence of continental discharge, as similar values are found at sites closest to the river mouth in western Africa [71-73]. Fluvial delivery is also suggested by the increase in $\mathrm{Ba}^{2+}$ core $\mathrm{X}$-ray fluorescence (XRF) data (Figure $5 \mathrm{~b}$ ), which are used to infer freshwater inputs [72,74]. Seawater Ba concentrations at oceanic sites influenced by riverine runoff have a notably high inverse correlation to salinity, because dissolved $\mathrm{Ba}$ is high in riverine water [75]. Saharan aquifers were found to be recharged during glacials [76] and such humid periods trigger the reactivation of the Tamanrasset river system in Western Sahara [15], part of which is the Cap Timiris canyon.

Shell weights closely follow SSD changes $\left(R^{2}=0.43, p<0.05, n=12\right)$ during the time interval analyzed (Figure $5 \mathrm{~d}$ ). The two samples that exhibit abnormally elevated shell masses within the record are also shown to be outliers in Figure $5 \mathrm{~d}$ plot and, according to the $\mathrm{CT}$ analysis performed in one of them, the specimens were four times more contaminated by clay impurities than the rest of the scanned samples. If these two contaminated samples are omitted, the correlation between weighed shell mass and geochemically reconstructed seawater densities becomes more significant $\left(R^{2}=0.74\right.$, $p<0.01, n=10)$. There is a weaker correlation with salinity $\left(R^{2}=0.41, p<0.05, n=10\right)$, while there is no significant correlation between shell weights and atmospheric $p \mathrm{CO}_{2}\left(R^{2}=0.16 p<0.10, n=12\right)$ during this period. Using the shell mass-density regression line to correct the elevated weights, a contamination of $2-3 \mu \mathrm{g}$ is found. If these corrections are applied then the slope of the regression line (0.38; Figure 5d) matches that of Zarkogiannis, et al. [7] (0.39), which appears to be characteristic for G. bulloides. On the basis of this relationship, the low shell weights recorded prior to MIS 6.1 (Figure 4a) can be explained by the freshening of Mauritanian waters. Furthermore, during this time interval, the $\mu \mathrm{CT}$ analysis showed that foraminifera shells have the lowest volume normalized weights and they are smaller, thinner, and of highest porosity (Table 1). The lowest porosities are found close to the peak interglacial, when all other shell characteristics are intermediate. The heaviest, thickest, and densest shells are indeed recorded during the increased shell mass event (132.2 ka), when specimens are also largest, but of intermediate porosity (test density). Increased shell wall thicknesses and shell and 
test densities are characteristics of increased biomineralization efforts and play a partial role in the observed increased shell masses.

Shell mass is an easy to measure, central feature of fossil planktonic foraminifera that reflects their physiology and provides clues regarding the ocean carbon cycle. Furthermore, the whole-shell weights of planktonic foraminifera picked from a narrow size range can provide a measure of the extent of surface ocean density changes. The consistency of the different shell mass records from Pliocene core material [11] to Miocene land section samples [77] proves that foraminifera weighing is a robust method for assessing the extent of pelagic biomineralization. However, the present study has shown that the degree of shell cleanliness can greatly affect weight measurements, imposing distortions to paleoceanographic interpretations. Nonetheless, the cleaning procedure remains unstandardized, and different laboratories currently use a variety of treatment methods. It becomes apparent that, in studies of planktonic foraminifera shell weight variations, it is of particular importance to ensure the removal of the detritus trapped within shell chambers and $\mu \mathrm{CT}$ scanning should complement such studies. Except for the degree of contamination, CT provides a wealth of information on the biometry and the preservation of the tests.

\section{Conclusions}

On the basis of a record of planktonic foraminifera shell weights from a sediment core in the eastern tropical north Atlantic, we provide evidence of steady carbonate productivity in the equatorial Atlantic Ocean during the last two climatic cycles. A multiproxy dissolution assessment found foraminiferal carbonate to be well preserved, and the consistency in the measured shell masses is a reliable indication of stable foraminifera biomineralization strength, independent of changes in atmospheric $p \mathrm{CO}_{2}$. We attribute this invariability in the mass of G. bulloides shells to the stability of the local hydrologic conditions, which also reveals stability in the position of the ITCZ during the last two glacial-interglacial stages. Furthermore, the enhanced preservation of the foraminiferal record indicates that the Cape Verde plateau remained under the influence of the non-corrosive NADW during the study interval.

The geochemical analysis of the samples surrounding the termination revealed a freshening of the surface waters prior to PGM, which coincided with freshwater pulses or the reactivation of a sub-Saharan drainage system. Furthermore, the reported relationship between G. bulloides shell weight and ambient seawater densities was verified, reinforcing the use of foraminifera shell weight as a hydrological indicator. The X-ray tomographic analysis of selected samples allowed the determination of volume normalized weights and revealed that the spike observed in the G. bulloides shell weight record during T-II is an artifact of specimen contamination by clay infillings. Overall, the tomographic analysis proved to be a very powerful micropaleontological tool for the determination of key shell characteristics (e.g., cell volume, shell thickness, porosity), which are important for paleoclimatic studies.

Supplementary Materials: The following are available online at http://www.mdpi.com/2077-1312/8/10/737/s1.

Author Contributions: Conceptualization and original draft preparation, S.D.Z.; Geochemical analyses and data curation, M.G.; X-ray micro computed tomographic analyses, V.F.; review and editing, P.G.M., G.K., V.F., H.D., A.A., and M.G.; supervision, A.A. All authors have read and agreed to the published version of the manuscript.

Funding: This research received no external funding. The article processing charges for this open-access publication were covered by the University of Athens.

Acknowledgments: We would like to thank the Geosciences department of the University of Bremen for providing sediment core material and scanning electron microscope facilities. We would also like to thank the three anonymous reviewers and the handling editorial team for their constructive comments, which helped to considerably improve this manuscript.

Conflicts of Interest: The authors declare no conflict of interest.

Availability of Supporting Data: Supporting micro-CT data of the scanned specimens used in the paper are available for inspection from the GigaScience database (GigaDB) repository [54]. The acquired geochemical and micropaleontological data are available in the Supplementary Tables. 


\section{References}

1. Weinkauf, M.F.G.; Moller, T.; Koch, M.C.; Kučera, M. Calcification intensity in planktonic Foraminifera reflects ambient conditions irrespective of environmental stress. Biogeosciences 2013, 10, 6639-6655. [CrossRef]

2. Lohmann, G.P. A model for variation in the chemistry of planktonic foraminifera due to secondary calcification and selective dissolution. Paleoceanography 1995, 10, 445-457. [CrossRef]

3. Barker, S.; Elderfield, H. Foraminiferal calcification response to glacial-interglacial changes in atmospheric $\mathrm{CO}_{2}$. Science 2002, 297, 833-836. [CrossRef] [PubMed]

4. De Villiers, S. Optimum growth conditions as opposed to calcite saturation as a control on the calcification rate and shell-weight of marine foraminifera. Mar. Biol. 2004, 144, 45-49. [CrossRef]

5. Aldridge, D.; Beer, C.J.; Purdie, D.A. Calcification in the planktonic foraminifera Globigerina bulloides linked to phosphate concentrations in surface waters of the North Atlantic Ocean. Biogeosciences 2012, 9, 1725-1739. [CrossRef]

6. Qin, B.; Li, T.; Xiong, Z.; Algeo, T.J.; Jia, Q. Calcification of planktonic foraminifer Pulleniatina obliquiloculata controlled by seawater temperature rather than ocean acidification. Glob. Planet. Chang. 2020, 193, 103256. [CrossRef]

7. Zarkogiannis, S.D.; Antonarakou, A.; Tripati, A.; Kontakiotis, G.; Mortyn, P.G.; Drinia, H.; Greaves, M. Influence of surface ocean density on planktonic foraminifera calcification. Sci. Rep. 2019, 9, 533. [CrossRef]

8. Zarkogiannis, S.D.; Kontakiotis, G.; Antonarakou, A.; Mortyn, P.G.; Drinia, H. Latitudinal Variation of Planktonic Foraminifera Shell Masses During Termination I. IOP Conf. Ser. Earth Environ. Sci. 2019, 221, 12052. [CrossRef]

9. Marszalek, D.S. The role of heavy skeletons in vertical movements of non-motile zooplankton. Mar. Behav. Physiol. 1982, 8, 295-303. [CrossRef]

10. Lipps, J.H. Ecology and paleoecology of planktic foraminifera. In Foraminiferal Ecology and Paleoecology; Lipps, J.H., Berger, W.H., Buzas, M.A., Douglas, R.G., Ross, C.A., Eds.; SEPM Society for Sedimentary Geology: Broken Arrow, OK, USA, 1979; Volume 6, pp. 62-104.

11. Davis, C.V.; Badger, M.P.S.; Bown, P.R.; Schmidt, D.N. The response of calcifying plankton to climate change in the Pliocene. Biogeosciences 2013, 10, 6131-6139. [CrossRef]

12. Barron, E.J. Tropical climate stability and implications for the distribution of life. In Effects of Past Global Change on Life; National Research Council, Ed.; The National Academies Press: Washington, DC, USA, 1995; pp. 108-117. [CrossRef]

13. Newell, R.E.; Navato, A.R.; Hsiung, J. Long-term global sea surface temperature fluctuations and their possible influence on atmospheric $\mathrm{CO}_{2}$ concentrations. Pure Appl. Geophys. 1978, 116, 351-371. [CrossRef]

14. Fox, L.; Stukins, S.; Hill, T.; Miller, C.G. Quantifying the Effect of Anthropogenic Climate Change on Calcifying Plankton. Sci. Rep. 2020, 10, 1620. [CrossRef] [PubMed]

15. Skonieczny, C.; Paillou, P.; Bory, A.; Bayon, G.; Biscara, L.; Crosta, X.; Eynaud, F.; Malaizé, B.; Revel, M.; Aleman, N.; et al. African humid periods triggered the reactivation of a large river system in Western Sahara. Nat. Commun. 2015, 6, 8751. [CrossRef]

16. Nicholson, S. A revised picture of the structure of the 'monsoon' and land ITCZ over West Africa. Clim. Dyn. 2009, 32, 1155-1171. [CrossRef]

17. Tulet, P.; Mallet, M.; Pont, V.; Pelon, J.; Boone, A. The 7-13 March 2006 dust storm over West Africa: Generation, transport, and vertical stratification. J. Geophys. Res. Atmos. 2008, 113. [CrossRef]

18. Holz, C.; Stuut, J.-B.W.; Henrich, R.; Meggers, H. Variability in terrigenous sedimentation processes off northwest Africa and its relation to climate changes: Inferences from grain-size distributions of a Holocene marine sediment record. Sediment. Geol. 2007, 202, 499-508. [CrossRef]

19. Peyrillé, P.; Lafore, J.-P.; Redelsperger, J.-L. An Idealized Two-Dimensional Framework to Study the West African Monsoon. Part I: Validation and Key Controlling Factors. J. Atmos. Sci. 2007, 64, 2765-2782. [CrossRef]

20. Aouni, A.E.; Daoudi, K.; Yahia, H.; Minaoui, K.; Benazzouz, A. Surface mixing and biological activity in the North-West African upwelling. Chaos Interdiscip. J. Nonlinear Sci. 2019, 29, 011104. [CrossRef] [PubMed]

21. Mittelstaedt, E. The ocean boundary along the northwest African coast: Circulation and oceanographic properties at the sea surface. Prog. Oceanogr. 1991, 26, 307-355. [CrossRef] 
22. Stramma, L.; Hóttl, S.; Schafstall, J. Water masses and currents in the upper tropical northeast Atlantic off northwest Africa. J. Geophys. Res. 2005, 110, C12006. [CrossRef]

23. Tomczak, M. An analysis of mixing in the frontal zone of South and North Atlantic Central Water off North-West Africa. Prog. Oceanogr. 1981, 10, 173-192. [CrossRef]

24. Tomczak, M.; Godfrey, J.S. Regional Oceanography: Introduction; Elsevier: New York, NY, USA, $1994 ;$ p. 422.

25. Howe, J.N.W.; Piotrowski, A.M.; Noble, T.L.; Mulitza, S.; Chiessi, C.M.; Bayon, G. North Atlantic Deep Water Production during the Last Glacial Maximum. Nat. Commun. 2016, 7, 11765. [CrossRef] [PubMed]

26. Barker, S.; Kiefer, T.; Elderfield, H. Temporal changes in North Atlantic circulation constrained by planktonic foraminiferal shell weights. Paleoceanography 2004, 19, PA3008. [CrossRef]

27. Beer, C.J.; Schiebel, R.; Wilson, P.A. Technical Note: On methodologies for determining the size-normalised weight of planktic foraminifera. Biogeosciences 2010, 7, 2193-2198. [CrossRef]

28. Broecker, W.; Clark, E. An evaluation of Lohmann's Foraminifera weight dissolution index. Paleoceanography 2001, 16, 531-534. [CrossRef]

29. Thunell, R.C.; Honjo, S. Calcite dissolution and the modification of planktonic foraminiferal assemblages. Mar. Micropaleontol. 1981, 6, 169-182. [CrossRef]

30. Volbers, A.N.A.; Henrich, R. Present water mass calcium carbonate corrosiveness in the eastern South Atlantic inferred from ultrastructural breakdown of Globigerina bulloides in surface sediments. Mar. Geol. 2002, 186, 471-486. [CrossRef]

31. Zarkogiannis, S.; Fernandez, V.; Greaves, M.; Mortyn, P.G.; Kontakiotis, G.; Antonarakou, A. X-ray tomographic data of planktonic foraminifera species Globigerina bulloides from the Eastern Tropical Atlantic across Termination II. Gigabyte 2020, 1. [CrossRef]

32. Iwasaki, S.; Kimoto, K.; Sasaki, O.; Kano, H.; Uchida, H. Sensitivity of planktic foraminiferal test bulk density to ocean acidification. Sci. Rep. 2019, 9, 9803. [CrossRef]

33. Mashiotta, T.A.; Lea, D.W.; Spero, H.J. Glacial-interglacial changes in Subantarctic sea surface temperature and $\delta^{18} \mathrm{O}$-water using foraminiferal Mg. Earth Planet. Sci. Lett. 1999, 170, 417-432. [CrossRef]

34. Kim, S.-T.; O'Neil, J.R. Equilibrium and non-equilibrium oxygen isotope effects in synthetic carbonates. Geochim. Cosmochim. Acta 1997, 61, 3461-3475. [CrossRef]

35. Hut, G. Consultants group meeting on stable isotope reference samples for geochemical and hydrological investigations. In Proceedings of the Report to the Director General of the International Atomic Energy Agency, Vienna, Austria, 16-18 September 1985; p. 42.

36. LeGrande, A.N.; Schmidt, G.A. Global gridded data set of the oxygen isotopic composition in seawater. Geophys. Res. Lett. 2006, 33, L12604. [CrossRef]

37. Fairbanks, R.G. A 17,000-year glacio-eustatic sea level record: Influence of glacial melting rates on the Younger Dryas event and deep-ocean circulation. Nature 1989, 342, 637-642. [CrossRef]

38. UNESCO. The International Thermodynamic Equation of Seawater-2010: Calculation and Use of Thermodynamic Properties; UNESCO: Paris, France, 2010; p. 196.

39. Barker, S.; Greaves, M.; Elderfield, H. A study of cleaning procedures used for foraminiferal $\mathrm{Mg} / \mathrm{Ca}$ paleothermometry. Geochem. Geophys. Geosyst. 2003, 4. [CrossRef]

40. De Villiers, S.; Greaves, M.; Elderfield, H. An intensity ratio calibration method for the accurate determination of $\mathrm{Mg} / \mathrm{Ca}$ and $\mathrm{Sr} / \mathrm{Ca}$ of marine carbonates by ICP-AES. Geochem. Geophys. Geosyst. 2002, 3. [CrossRef]

41. Greaves, M.; Barker, S.; Daunt, C.; Elderfield, H. Accuracy, standardization, and interlaboratory calibration standards for foraminiferal Mg/Ca thermometry. Geochem. Geophys. Geosyst. 2005, 6. [CrossRef]

42. Greaves, M.; Caillon, N.; Rebaubier, H.; Bartoli, G.; Bohaty, S.; Cacho, I.; Clarke, L.; Cooper, M.; Daunt, C.; Delaney, M.; et al. Interlaboratory comparison study of calibration standards for foraminiferal $\mathrm{Mg} / \mathrm{Ca}$ thermometry. Geochem. Geophys. Geosyst. 2008, 9. [CrossRef]

43. Rosenthal, Y.; Perron-Cashman, S.; Lear, C.H.; Bard, E.; Barker, S.; Billups, K.; Bryan, M.; Delaney, M.L.; de Menocal, P.B.; Dwyer, G.S.; et al. Interlaboratory comparison study of $\mathrm{Mg} / \mathrm{Ca}$ and $\mathrm{Sr} / \mathrm{Ca}$ measurements in planktonic foraminifera for paleoceanographic research. Geochem. Geophys. Geosyst. 2004, 5. [CrossRef]

44. Petit, J.R.; Jouzel, J.; Raynaud, D.; Barkov, N.I.; Barnola, J.M.; Basile, I.; Bender, M.; Chappellaz, J.; Davis, M.; Delaygue, G.; et al. Climate and atmospheric history of the past 420,000 years from the Vostok ice core, Antarctica. Nature 1999, 399, 429-436.

45. Colleoni, F.; Wekerle, C.; Näslund, J.-O.; Brandefelt, J.; Masina, S. Constraint on the penultimate glacial maximum Northern Hemisphere ice topography ( $\approx 140$ kyrs BP). Quat. Sci. Rev. 2016, 137, 97-112. [CrossRef] 
46. Siddall, M.; Rohling, E.J.; Almogi-Labin, A.; Hemleben, C.; Meischner, D.; Schmelzer, I.; Smeed, D.A. Sea-level fluctuations during the last glacial cycle. Nature 2003, 423, 853-858. [CrossRef] [PubMed]

47. Wien, K.; Holz, C.; Kölling, M.; Schulz, H.D. Geochemical data (solid phase) of sediment core GeoB8502-2. Pangaea 2006. [CrossRef]

48. Davis, C.V.; Rivest, E.B.; Hill, T.M.; Gaylord, B.; Russell, A.D.; Sanford, E. Ocean acidification compromises a planktic calcifier with implications for global carbon cycling. Sci. Rep. 2017, 7, 2225. [CrossRef]

49. Liou, K.-N. Radiation climatology. In International Geophysics; Academic Press: Cambridge, MA, USA, 1980; Volume 26, pp. 293-348.

50. Barker, S.; Archer, D.; Booth, L.; Elderfield, H.; Henderiks, J.; Rickaby, R.E.M. Globally increased pelagic carbonate production during the Mid-Brunhes dissolution interval and the $\mathrm{CO}_{2}$ paradox of MIS 11. Quat. Sci. Rev. 2006, 25, 3278-3293. [CrossRef]

51. Johnson, G.C.; Schmidtko, S.; Lyman, J.M. Relative contributions of temperature and salinity to seasonal mixed layer density changes and horizontal density gradients. J. Geophys. Res. Oceans 2012, 117. [CrossRef]

52. Moy, A.D.; Howard, W.R.; Bray, S.G.; Trull, T.W. Reduced calcification in modern Southern Ocean planktonic foraminifera. Nat. Geosci. 2009, 2, 276-280. [CrossRef]

53. Berger, A. Milankovitch Theory and climate. Rev. Geophys. 1988, 26, 624-657. [CrossRef]

54. Zarkogiannis, S.; Fernandez, V.; Greaves, M.; Mortyn, P.G.; Kontakiotis, G.; Antonarakou, A. Supporting data for "X-ray tomographic data of planktonic foraminifera species Globigerina bulloides from the Eastern Tropical Atlantic across Termination II". GigaScience Database 2020. [CrossRef]

55. Berger, W.H.; Bonneau, M.C.; Parker, F.L. Foraminifera on the deep-sea floor: Lysocline and dissolution rate. Oceanol. Acta 1982, 5, 249-258.

56. Ruddiman, W.F. Pleistocene Sedimentation in the Equatorial Atlantic: Stratigraphy and Faunal Paleoclimatology. Geol. Soc. Am. Bull. 1971, 82, 283-302. [CrossRef]

57. Curry, W.B.; Lohmann, G.P. Late Quaternary carbonate sedimentation at the Sierra Leone Rise (eastern equatorial Atlantic Ocean). Mar. Geol. 1986, 70, 223-250. [CrossRef]

58. Prell, W.L. Late Pleistocene Faunal, Sedimentary and Temperature History of the Columbia Basin, Caribbean Sea; Columbia University: New York, NY, USA, 1974.

59. Damuth, J.E. The Western Equatorial Atlantic Morphology, Quaternary Sediments, and Climatic Cycles; Columbia University: New York, NY, USA, 1973.

60. Broecker, W.S.; Turekian, K.K.; Heezen, B.C. The relation of deep sea [Atlantic Ocean] sedimentation rates to variations in climate. Am. J. Sci. 1958, 256, 503-517. [CrossRef]

61. Hays, J.D.; Perruzza, A. The Significance of Calcium Carbonate Oscillations in Eastern Equatorial Atlantic deep-Sea Sediments for the End of the Holocene Warm Interval. Quat. Res. 1972, 2, 355-362. [CrossRef]

62. Bacon, M.P. Glacial to interglacial changes in carbonate and clay sedimentation in the Atlantic Ocean estimated from ${ }^{230}$ Th measurements. Chem. Geol. 1984, 46, 97-111. [CrossRef]

63. Curry, W.B.; Cullen, J.L. Carbonate production and dissolution in the western equatorial Atlantic during the last 1 MY. In Proceedings of the Ocean Drilling Program, Scientific Results, Charleston, SC, USA, 8 January-14 February 1997; Volume 154, p. 189. [CrossRef]

64. Eglinton, G.; Bradshaw, S.; Resell, A.; Sarnthein, M.; Pflaumann, U.; Tiedemann, R. Molecular record of secular sea surface temperature changes on 100-year timescales for glacial terminations I, II and IV. Nature 1992, 356, 423-426. [CrossRef]

65. Speth, P.; Detlefsen, H.; Sierts, H.-W. Meteorological influence on upwelling off Northwest Africa. Ocean Dyn. 1978, 31, 95-104. [CrossRef]

66. CLIMAP-Project-Members. The last interglacial ocean. Quat. Res. 1984, 21, 123-224. [CrossRef]

67. Sarnthein, M.; Tiedemann, R. Younger Dryas-style cooling events at glacial Terminations I-VI at ODP Site 658: Associated benthic $\delta^{13} \mathrm{C}$ anomalies constrain meltwater hypothesis. Paleoceanography 1990, 5, 1041-1055. [CrossRef]

68. Grant, K.M.; Rohling, E.J.; Ramsey, C.B.; Cheng, H.; Edwards, R.L.; Florindo, F.; Heslop, D.; Marra, F.; Roberts, A.P.; Tamisiea, M.E.; et al. Sea-level variability over five glacial cycles. Nat. Commun. 2014, 5, 5076. [CrossRef]

69. Grant, K.M.; Rohling, E.J.; Bar-Matthews, M.; Ayalon, A.; Medina-Elizalde, M.; Ramsey, C.B.; Satow, C.; Roberts, A.P. Rapid coupling between ice volume and polar temperature over the past 150,000 years. Nature 2012, 491, 744-747. [CrossRef] 
70. Marino, G.; Rohling, E.J.; Rodríguez-Sanz, L.; Grant, K.M.; Heslop, D.; Roberts, A.P.; Stanford, J.D.; Yu, J. Bipolar seesaw control on last interglacial sea level. Nature 2015, 522, 197-201. [CrossRef] [PubMed]

71. Dupont, L.M.; Weinelt, M. Vegetation history of the savanna corridor between the Guinean and the Congolian rain forest during the last 150,000 years. Vegetat. Hist. Archaeobot. 1996, 5, 273-292. [CrossRef]

72. Weldeab, S.; Lea, D.W.; Schneider, R.R.; Andersen, N. 155,000 years of West African monsoon and ocean thermal evolution. Science 2007, 316, 1303-1307. [CrossRef] [PubMed]

73. Sierro, F.J.; Hodell, D.A.; Andersen, N.; Azibeiro, L.A.; Jimenez-Espejo, F.J.; Bahr, A.; Flores, J.A.; Ausin, B.; Rogerson, M.; Lozano-Luz, R.; et al. Mediterranean Overflow over the Last 250 kyr: Freshwater Forcing from the Tropics to the Ice Sheets. Paleoceanogr. Paleoclimatol. 2020, 35, e2020PA003931. [CrossRef]

74. Grant, K.M.; Grimm, R.; Mikolajewicz, U.; Marino, G.; Ziegler, M.; Rohling, E.J. The timing of Mediterranean sapropel deposition relative to insolation, sea-level and African monsoon changes. Quat. Sci. Rev. 2016, 140, 125-141. [CrossRef]

75. Coffey, M.; Dehairs, F.; Collette, O.; Luther, G.; Church, T.; Jickells, T. The Behaviour of Dissolved Barium in Estuaries. Estuar. Coast. Shelf Sci. 1997, 45, 113-121. [CrossRef]

76. Abouelmagd, A.; Sultan, M.; Milewski, A.; Kehew, A.E.; Sturchio, N.C.; Soliman, F.; Krishnamurthy, R.V.; Cutrim, E. Toward a better understanding of palaeoclimatic regimes that recharged the fossil aquifers in North Africa: Inferences from stable isotope and remote sensing data. Palaeogeogr. Palaeoclimatol. Palaeoecol. 2012, 329-330, 137-149. [CrossRef]

77. Kontakiotis, G.; Besiou, E.; Antonarakou, A.; Zarkogiannis, S.D.; Kostis, A.; Mortyn, P.G.; Moissette, P.; Cornée, J.J.; Schulbert, C.; Drinia, H.; et al. Decoding sea surface and paleoclimate conditions in the eastern Mediterranean over the Tortonian-Messinian Transition. Palaeogeogr. Palaeoclimatol. Palaeoecol. 2019, 534, 109312. [CrossRef]

(C) 2020 by the authors. Licensee MDPI, Basel, Switzerland. This article is an open access article distributed under the terms and conditions of the Creative Commons Attribution (CC BY) license (http://creativecommons.org/licenses/by/4.0/). 